Article

\title{
Fe-Al Phosphate Microcrystals in Pedogenic Goethite Pisoliths
}

\author{
János Kovács ${ }^{1,2, *} \mathbb{D}$, Éva Farics ${ }^{2}$, Péter Szabó ${ }^{1,2}$ and István Sajó ${ }^{1}$ \\ 1 Szentágothai Research Centre, Environmental Analytical and Geoanalytical Research Group, University of \\ Pécs, Ifjúság u. 20, H-7624 Pécs, Hungary; szabopet@gamma.ttk.pte.hu (P.S.); istvan.sajo@gmail.com (I.S.) \\ 2 Department of Geology and Meteorology, University of Pécs, Ifjúság u. 6, H-7624 Pécs, Hungary; \\ faricse@gamma.ttk.pte.hu \\ * Correspondence: jones@gamma.ttk.pte.hu
}

Received: 2 March 2020; Accepted: 15 April 2020; Published: 16 April 2020

check for updates

\begin{abstract}
In sedimentary rocks, Fe-Al phosphate minerals occur in different rocks and depositional environments. Herein, we present microcrystals of wavellite, crandallite, and cacoxenite from pedogenic goethite pisoliths and nodules. Pisoliths and nodules are generally dominated by Fe oxides and oxihydroxides. Frequently, pisoliths and nodules demonstrate high phosphatization and a substantial contribution of allogenic detritus. The aim of our study is to present these remarkable crystals found in goethites. We describe the geochemistry and mineralogy of the pisoliths and try to interpret the possible paragenesis of the minerals. Loose ferruginous pisoliths and nodules are separated from the red paleosol and analyzed using field emission scanning electron microscope (FE-SEM) coupled with the energy dispersive X-ray detector (EDS), X-ray fluorescence spectroscopy (XRF), and X-ray powder diffraction (XRD) methods. The studied paleosols are weathered in a subtropical climate and the newly formed precipitation products, such as crandallite, wavellite, cacoxenite, and goethite, accumulate during the weathering of apatite.
\end{abstract}

Keywords: wavellite; crandallite; cacoxenite; adsorption; microcrystals; goethite; pisolith

\section{Introduction}

Several hundred phosphate minerals are known, virtually all of which are orthophosphates. All known phosphate minerals (more than 150 species) are orthophosphates with monovalent, divalent, or trivalent cations forming polyhedra and then usually tetrahedra $\left(\mathrm{PO}_{4}\right)$ with quite complex crystal chemistry [1,2]. In this study, we deal with three Fe phosphate minerals, namely cacoxenite, wavellite, and crandallite.

Geologically, cacoxenite is a common secondary mineral associated with iron ores [3,4] and phosphate ores $[4,5]$. More rarely, cacoxenite can be found in iron and manganese-bearing novaculites and some iron-rich soils or beach sediments [6]. Cacoxenite can be found in more than 150 deposits across the globe [3]. Cacoxenite, ideally $\left(\mathrm{Fe}^{3+}, \mathrm{Al}\right)_{25}\left(\mathrm{PO}_{4}\right)_{17} \mathrm{O}_{6}(\mathrm{OH})_{12} \cdot 75\left(\mathrm{H}_{2} \mathrm{O}\right)$, was first described by Steinmann [7], and the mineral was found in Zaječov (Czech Republic).

Wavellite, preferably $\mathrm{Al}_{3}\left(\mathrm{PO}_{4}\right)_{2}(\mathrm{OH}, \mathrm{F})_{3} \cdot 5 \mathrm{H}_{2} \mathrm{O}$, is a secondary $\mathrm{Al}$ phosphate occurring in $\mathrm{Fe}$ deposits with large $\mathrm{P}$ contents. It is rarely found as well developed single crystals and shows typically spherulitic aggregates composed of radiating acicular crystals [8]. The perfect cleavage of the crystal is in the (110) plane and good cleavage in the (101) plane [8]. Although wavellite is one of the most widespread secondary Al phosphates, studies on its crystal chemistry are rare. A working description of the wavellite crystal structure was provided by Huminicki and Hawthorne [9] in their classification of phosphate minerals. 
Crandallite is a calcium and aluminum hydroxy phosphate, part of the alunite supergroup of minerals, and belongs to the plumbogummite group with $-1 c$ (single unit cell) [10]. Crandallite, ideally $\mathrm{CaAl}_{3}\left(\mathrm{PO}_{4}\right)_{2}(\mathrm{OH})_{5} \cdot\left(\mathrm{H}_{2} \mathrm{O}\right)$, is a trigonal mineral and found in considerable quantities in lateritic phosphate rock deposits and forms compact cleavable or fibrous masses [11].

Phosphorus exists in mineral forms such as strengite, vivianite, and especially as apatite minerals in soil parent rock (unaltered bedrock) [12]. Different factors, such as parent material, weathering, transformation time, climate, organisms, and special processes involved in soil formation, transform the primary minerals into stable pedogenic minerals in thermodynamic equilibrium [12]. Therefore, phosphorus from essential minerals is released into the soil solution. Modification of aluminum and iron into oxides or oxyhydroxides creates new specific substituents for phosphorus adsorption. The dynamic processes that include dissolution, precipitation, adsorption, and desorption make a significant contribution to pedogenesis together with phosphate retention in iron oxide systems [13-16]. Well-characterized iron and aluminum phosphates (e.g. strengite, vivianite) occur in some ferralsols (oxisols) and lateritic, sesquioxide-rich soil horizons. They have turned out to be more frequent together with a broad spectrum of other Fe-Al phosphates in paleosols, duricrusts, and lateritic deposits $[4,14,17,18]$. For such cases where Fe abounds over $\mathrm{Al}$, pisolitic iron ores ("Bohnerz" or bean ores) developed under humid tropical to subtropical climatic conditions [19].

Goethite and hematite are the most common pedogenic iron oxides, accompanied by various Fe oxides, such as lepidocrocite and maghemite in small quantities [20-23]. In humid and temperate climates, ferrihydrite, and sometimes lepidocrocite, might be dominant pedogenic iron oxides [20-24]. As stated by Cornell and Schwertmann [24], the occurrence of goethite is favored by an acid $\mathrm{pH}$ and a high organic matter content of the soil, which usually demonstrates a higher affinity for phosphate relative to organic acids for goethite than for hematite $[23,25]$.

Extrabasinal (allochthonous) deposits and soil profiles are rich in pisoliths and nodules in many parts of the world [26-28], and quite common in most parts of the tropics and subtropics, in many landscape positions ranging from unconsolidated colluvial pisolitic gravel deposits to cemented duricrusts, and they may be associated with lateritic deep weathering [29]. Distinct ferruginous sub-spherical grains have a wide range of compositions containing primarily iron sesquioxides, aluminum and manganese oxides with variable combinations of clay minerals (mainly kaolinite), titanium oxide, quartz, and other weathering-resistant minerals [30]. These materials occur from sub-surface zones to the surface in deeply weathered terrains. Pisoliths and nodules are spheroidal grains in soils 2-64 $\mathrm{mm}$ in size and comprising soil-particle aggregates, mineral particles such as quartz, hematite/goethite, or lithic fragments [30]. Ferruginous pisoliths and nodules are a frequent component of many catena and weathering profiles in the tropical and subtropical regions and also in temperate regions [29,31-34]. These low-temperature geochemical sediments vary in size and genesis. There are detrital and accretionary types, well-rounded and highly angular in shape [31]. Regarding their size, the ooliths are the smallest grains $(<2 \mathrm{~mm}$ in diameter), then there are the pisoliths $(2-5 \mathrm{~mm})$ and nodules ( $5 \mathrm{~mm}$ up to $3 \mathrm{~cm}$ ), and the biggest ones are concretions ( $>3 \mathrm{~cm}$ in diameter) [31,34].

The mineralogy of cacoxenite, wavellite, and crandallite, and their interrelationship with goethite, is presented in this study, and based upon these investigations, the origin of the low-temperature goethite-phosphate mineralization is discussed. A combination of chemical and mineralogical techniques is used to interpret the paragenesis of these micro-sized minerals. Moreover, to our knowledge, there is no work in the literature showing microscale cacoxenite, wavellite, and crandallite crystals from pedogenic goethite pisoliths.

\section{Materials and Methods}

\subsection{Characterization of Materials}

Pedogenic goethite pisoliths and nodules $(n=7)$ were sampled from Pliocene-Lower Pleistocene red clay deposits (paleosols) in the Carpathian Basin (Central Europe) [35,36]. Detailed information 
regarding the geological setting of these red paleosols can be seen in Kovács et al. [35,36]. Pisoliths are 2-5 mm, nodules are $5 \mathrm{~mm}$ up to $3 \mathrm{~cm}$ in diameter (Figure 1), with homogeneous goethitic composition with internal mottles and syneresis cracks. Following Clarke and Chenoweth's [31] classification, these are syneresis, mottled, and homogeneous goethitic pisoliths.

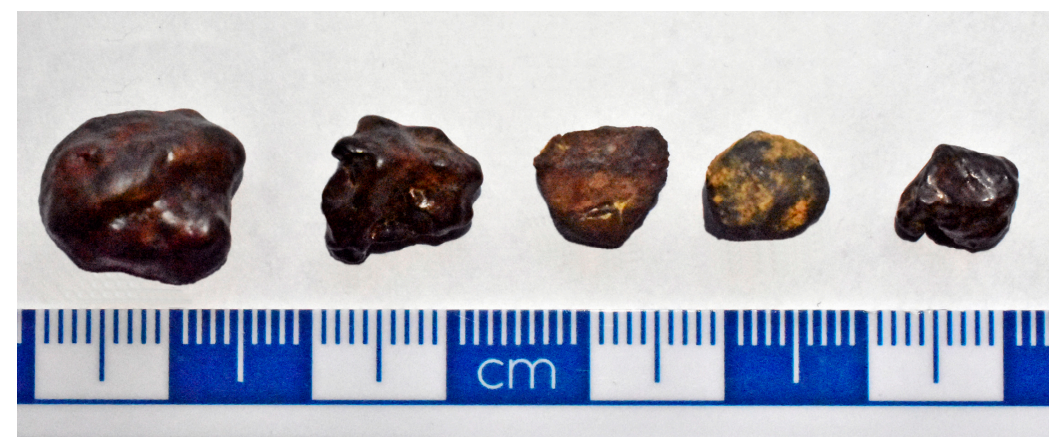

Figure 1. Examples of different size goethite pisoliths and nodules.

The host sediment, red clays and paleosols (ferralsols/oxisols), have a reddish-yellow (7.5YR 7/6) or reddish-brown (5YR 5/4) color. The reddish color of paleosols is attributed to hematite, the reddish-yellow (orange) is lepidocrocite, and the reddish-brown is ferrihydrite and/or nanocrystalline Fe oxide, formed pedogenically or during early diagenesis as the result of dehydration or dehydroxylation of Fe oxyhydroxides, or they may be inherited from the parent material $[24,35,36]$.

\subsection{Geochemical Analyses}

Pisolith and nodule samples were analyzed for major and trace element abundances with X-ray fluorescence spectrometry (XRF) using a Thermo ARL Advant'XP+ sequential XRF spectrometer in the GeoAnalytical Laboratory of Washington State University, Pullman, WA, USA. Due to the specific amount of sample needed for the analyses, the pisolith and nodule samples (from the given site) were mixed and homogenized. In this case, the major element compositions are average results of two-three samples from the given sites. The sample preparation procedures are described in detail by Kovács et al. [36]. The major element concentrations are expressed as wt. \%, volatile-free, with all the iron expressed as $\mathrm{Fe}_{2} \mathrm{O}_{3}$. Loss on ignition (LOI) was obtained by weighing after $16 \mathrm{~h}$ of calcination at $900{ }^{\circ} \mathrm{C}$. Analytical uncertainties are $\pm 2 \%$ for the major elements (except $\mathrm{Na}_{2} \mathrm{O}$ ).

\subsection{X-Ray Diffraction}

The XRD patterns on the pisoliths and nodules were collected using $\mathrm{Cu}-\mathrm{K} \alpha$ radiation $(40 \mathrm{kV}$, $15 \mathrm{~mA}$ ) with a Rigaku MiniFlex 600 (Rigaku, Tokyo, Japan). Scans were made at room temperature from 5 to $70^{\circ} 2 \theta$, with a step of $0.02 / \mathrm{s}$. XRD scans were evaluated for quantitative phase composition using a full profile fit procedure (XDB approach). The total amount of identified (crystalline) phases is taken as $100 \%$. Owing to the unknown proportion of amorphous components, the phase percentages reflect only relative abundances. The measurement uncertainties are $\pm 1 \%$, due to the precise sample preparation and measurement. The XDB method takes advantage of the fact that scale factors and phase weights can be determined without the knowledge and refinement of structural parameters. This software integrates the full profile fit with the mass balance approach and the specialized reference datasets. Further details about the XDB method can be found in Feret [37].

Crystallite size estimation of the minerals was made using XDB software (Version 1.7, Aluterv-FKI Ltd., Budapest, Hungary). The crystallite size results can be seen in the Supplementary file. The results were used for specific surface area (SSA) calculations. 


\subsection{Scanning Electron Microscopy and Elemental Analysis}

The surface morphology and chemical composition of the microcrystals and pisoliths/nodules were studied using a field-emission scanning electron microscope (FE-SEM) FEI Quanta FEG 650 (FEI, Hillsboro, OR, USA) and Jeol JSM-IT500HR (Jeol, Tokyo, Japan), coupled with an energy dispersive X-ray (EDS) Jeol DrySD SDD detector (Jeol, Tokyo, Japan), and set at an accelerating voltage of 3.0-5.0-10.0 kV and at 500-200,000× magnification. The raw samples (without coating) were observed both in high and low vacuum modes. New developments in energy dispersive X-ray spectrometry (EDS) on scanning electron microscopes provide a more precise analytical opportunity for quantitative and qualitative mineralogy characterization. Silicon drift energy dispersive X-ray detector (SDD) technology, with its high count rates, good energy resolution, and large effective area, permits characterizing minerals within seconds. Extended atomic databases included in the EDS software improve the identification and quantification of elements with overlapping peaks, due to the thin active layer which suppresses the Compton background [38-40].

\section{Results}

\subsection{Mineralogy and Geochemistry of the Pedogenic Pisoliths}

\subsubsection{XRD Analysis}

For quantitative mineralogical analysis, the XDB method was applied. Through bulk X-ray powder diffraction analysis of selected pisoliths and nodules, several minerals were identified (Figure 2). Goethite is the main mineral in pisoliths and nodules beside quartz, hematite muscovite, and kaolinite.

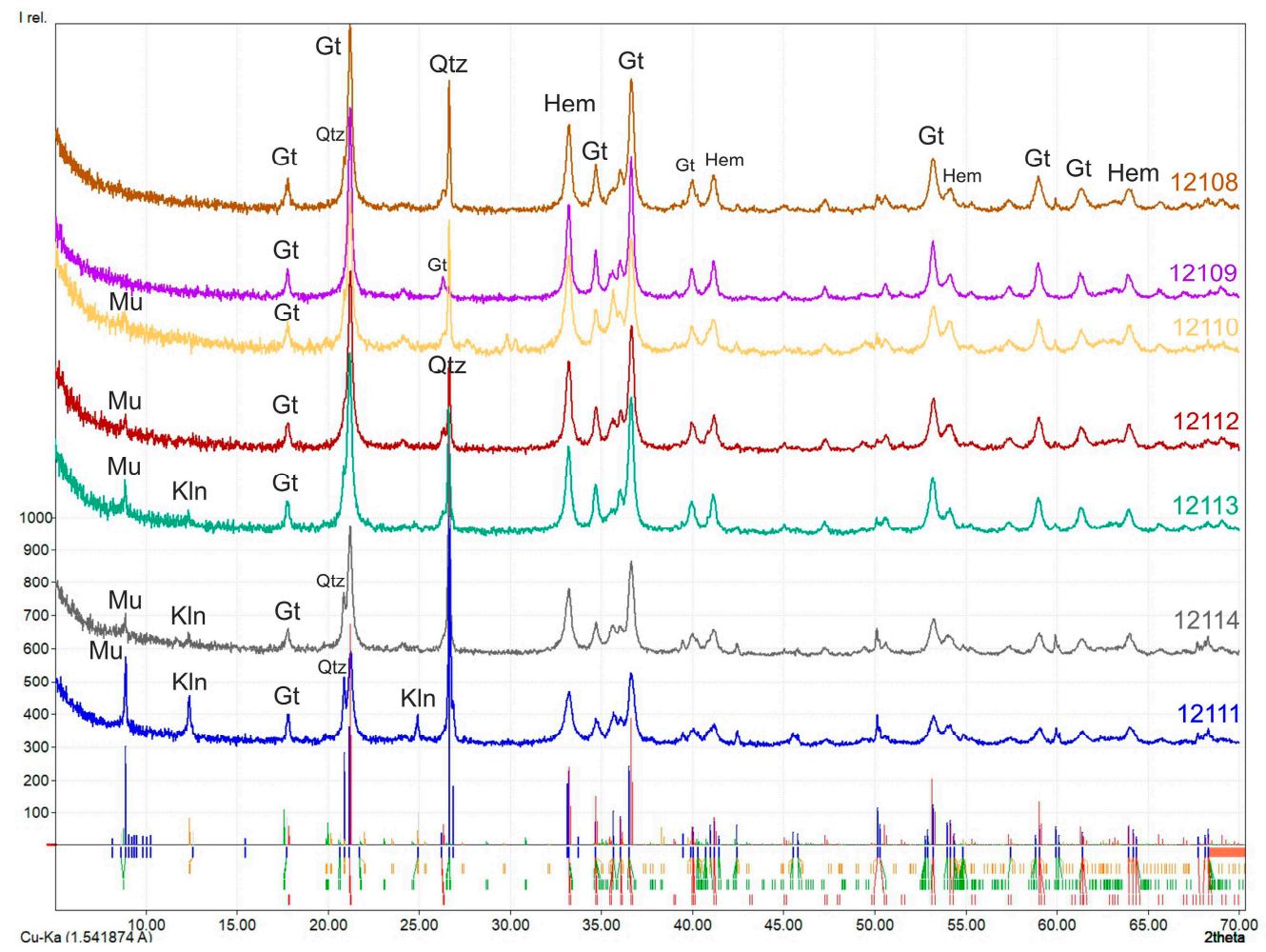

Figure 2. XRD patterns of the pisolith samples. Mu-muscovite; Kln-kaolinite; Gt-goethite; Qtz-quartz; Hem-hematite. The numbers (12108, etc.) denote sample numbers. The intensity scale is the same for all the patterns. (Individual XRD patterns with additional information are in the Supplementary file). 
The Fe-hydroxides and Fe-oxides dominate in the samples, which is typical of aerobic environments. The goethite content varies from $55 \%$ to $82 \%$, and the hematite from $5 \%$ to $12 \%$ (Table 1 ). The hematite/goethite ratio is very low (0.062-0.160) in the samples showing highly weathered source sediment (paleosol). Clay minerals, such as kaolinite, indicate subtropical weathering of the parent material. Detailed quantitative analyses by the XDB method can be found in the Supplementary file.

Table 1. Calculated goethite, hematite, and quartz content from mineral phases.

\begin{tabular}{cccc}
\hline Sample & Goethite (\%) & Hematite (\%) & Quartz (\%) \\
\hline 12108 & 80.9 & 5.0 & 5.0 \\
12109 & 82.6 & 7.5 & 0.5 \\
12110 & 74.6 & 12.0 & 5.0 \\
12111 & 55.7 & 7.0 & 13.0 \\
12112 & 79.1 & 8.0 & 4.0 \\
12113 & 77.3 & 5.0 & 5.0 \\
12114 & 69.2 & 8.0 & 12.0 \\
\hline
\end{tabular}

\subsubsection{The Specific Surface Area (SSA) Estimation}

The specific surface area of the minerals can be calculated using Formula (1) [41]. The SSA is calculated for goethite and hematite in this study. The calculated results are in Table 2.

$$
\mathrm{SSA}=6 \times 10^{3} / D_{\mathrm{p}} \rho,
$$

where $D_{\mathrm{p}}$ is the crystallite size, and $\rho$ is the density of the mineral.

Table 2. The specific surface area of goethite and hematite.

\begin{tabular}{cccc}
\hline Mineral & Crystallite Size $(\mathbf{n m})$ & Density $\left(\mathbf{g} \cdot \mathbf{c m}^{-\mathbf{3}}\right)$ & $\mathbf{S S A}\left(\mathbf{m}^{\mathbf{2}} \cdot \mathbf{g}^{-\mathbf{1}}\right)$ \\
\hline Goethite & 49 & 4.28 & 28.60 \\
Hematite & 49 & 5.26 & 23.27 \\
\hline
\end{tabular}

It is important to note that the SSA calculations are based on tentative data. Both crystallite size and density were estimated rather than measured. Crystallite sizes were calculated from XRD results, and therefore these are the dimensions perpendicular to just one crystallographic direction dependent on the peak chosen for calculations - and the Fe oxides in the nodules are not isometric. Density values are for pure $\alpha-\mathrm{FeOOH}$ and pure $\alpha-\mathrm{Fe}_{2} \mathrm{O}_{3}$, without any admixtures, vacancies, adsorbed water, etc.

\subsubsection{XRF Analysis}

Results of the whole-rock XRF analysis of goethite pisoliths are shown in Table 3, where the major and minor oxides are presented in weight percent (wt. \%). There is a relatively high content of $\mathrm{Fe}_{2} \mathrm{O}_{3}$ in the pisoliths, in contrast to the low concentrations of $\mathrm{SiO}_{2}$ and the alkaline earth metal oxides such as $\mathrm{CaO}, \mathrm{MgO}, \mathrm{Na}_{2} \mathrm{O}$, and $\mathrm{K}_{2} \mathrm{O}$ in the pisoliths (Table 3). This result demonstrates that the soluble constituents $\left(\mathrm{CaO}, \mathrm{MgO}, \mathrm{Na}_{2} \mathrm{O}\right.$, and $\left.\mathrm{K}_{2} \mathrm{O}\right)$ are leached, while the insoluble constituents $\left(\mathrm{SiO}_{2}\right.$, $\mathrm{Al}_{2} \mathrm{O}_{3}$, and $\mathrm{Fe}_{2} \mathrm{O}_{3}$ ) are accumulated as oxides/hydroxides during surface and sub-surface weathering processes. Major element patterns $\left(\mathrm{Fe}_{2} \mathrm{O}_{3}, \mathrm{SiO}_{2}, \mathrm{P}_{2} \mathrm{O}_{5}\right.$, and $\left.\mathrm{Al}_{2} \mathrm{O}_{3}\right)$ represent $\sim 87-89 \%$ of all pisolith contents, reflecting the predominance of goethite, hematite, quartz, and phyllosilicate. The iron oxide $\left(\mathrm{Fe}_{2} \mathrm{O}_{3}\right)$ content average is $68.14 \%$, while $\mathrm{MnO}$ is very low, averaging $0.143 \%$. $\mathrm{TiO}_{2}, \mathrm{Na}_{2} \mathrm{O}, \mathrm{CaO}, \mathrm{MgO}$, and $\mathrm{K}_{2} \mathrm{O}$ concentrations are lower than $1 \%$. Comparing these results to the average paleosol chemical content (see Table 3), we conclude that the pisoliths are depleted in $\mathrm{SiO}_{2}, \mathrm{Al}_{2} \mathrm{O}_{3}, \mathrm{TiO}_{2}, \mathrm{MgO}$, and $\mathrm{K}_{2} \mathrm{O}$, and enriched in $\mathrm{Fe}_{2} \mathrm{O}_{3}$ and $\mathrm{P}_{2} \mathrm{O}_{5}$. 
Table 3. Major element compositions (wt. \%) of pisolith samples (recalculated on a volatile-free basis).

\begin{tabular}{cccccccccccc}
\hline Sample & $\mathbf{S i O}_{2}$ & $\mathrm{Al}_{2} \mathbf{O}_{3}$ & $\mathbf{F e}_{2} \mathbf{O}_{3}$ & $\mathrm{TiO}_{2}$ & $\mathbf{C a O}$ & $\mathbf{M g O}$ & $\mathbf{M n O}$ & $\mathbf{K}_{2} \mathbf{O}$ & $\mathbf{N a}_{2} \mathbf{O}_{2}$ & $\mathbf{P}_{\mathbf{2}} \mathbf{O}_{5}$ & $\mathbf{L O I}^{* *}$ \\
\hline 12108 & 24.0 & 5.30 & 57.1 & 0.190 & 0.32 & 0.72 & 0.101 & 0.86 & 0.470 & 1.560 & 8.71 \\
12109 & 6.0 & 1.48 & 80.3 & 0.111 & 0.26 & 0.58 & 0.037 & 0.32 & 0.015 & 1.071 & 9.10 \\
12110 & 20.4 & 4.45 & 62.9 & 0.170 & 0.42 & 0.55 & 0.150 & 0.71 & 0.470 & 1.130 & 8.21 \\
12111 & 24.2 & 5.40 & 57.5 & 0.230 & 0.68 & 0.95 & 0.072 & 0.89 & 0.440 & 1.170 & 8.07 \\
12112 & 8.6 & 3.02 & 76.2 & 0.127 & 0.15 & 0.42 & 0.050 & 0.26 & 0.009 & 1.220 & 9.60 \\
12113 & 17.3 & 4.05 & 65.0 & 0.200 & 0.79 & 0.39 & 0.043 & 0.75 & 0.170 & 1.460 & 9.99 \\
12114 & 9.7 & 2.28 & 75.0 & 0.127 & 0.64 & 0.49 & 0.250 & 0.40 & 0.074 & 1.260 & 9.10 \\
Average paleosols * & 56.5 & 18.6 & 6.95 & 0.89 & 1.45 & 2.45 & 0.1 & 2.35 & 0.45 & 0.11 & 10.6 \\
\hline
\end{tabular}

* Data from Kovács et al. [42]. ** Loss on ignition.

The loss on ignition (LOI) values of the samples was found to be within the range of 9.21-10.60\% (Table 3). The LOI is high due to dehydroxylation. The relatively higher LOI indicates the presence of a high content of leachable matter during weathering, in other words, it indicates the highly altered nature of the analyzed samples.

\subsection{SEM-EDX Analysis}

\subsubsection{Goethite Pisoliths and Nodules}

SEM micrographs show iron oxide crystallites within the grains, where the structure is massive (Figure 3a and Figure 6a), while close to the pores they present remarkable growth patterns (goethite palisades) (Figure 3b,c). Elemental mapping by EDS clearly shows the colloform rhythmites of pure goethite (Figure 3a). Based on the chemical mapping results, the mammillary shape area (Figure 3a) is ferriallophane $\left(x \mathrm{Al}_{2} \mathrm{O}_{3} \cdot y \mathrm{Fe}_{2} \mathrm{O}_{3} \cdot z \mathrm{SiO}_{2} \cdot n \mathrm{H}_{2} \mathrm{O}\right)$. Micromorphology (clusters of pseudohexagonal plates) and elemental analyses indicate that the Al-dominated minerals are kaolinites (Figure 4). There are some amounts of sodium and magnesium that are not usually present in kaolinite, but Figure 4 reveals that both these elements are rather dispersed throughout the sample (also in Fe oxide-rich areas), and only slightly concentrated in the Al-rich area (hence it might be related to e.g. sorption). Phosphates seem enriched in micro-veins, as can be seen in Figure 3d.

\subsubsection{Phosphate Minerals}

Wavellite, crandallite, and cacoxenite crystals are restricted to vugs and solution cavities, they stand out by their needle-shaped aggregates (Figures 5 and 6). The dimension of the vugs varied between 50 and $100 \mu \mathrm{m}$ diameter.

Wavellite microcrystals are $\sim 20 \mu \mathrm{m}$ long and have needles that form broom-like aggregates (Figure 5a,b). Acicular crystals such as in our sample are rare, stout to long prismatic parallel to [001], with $\{110\}$ striated parallel to [001] (Figure 5b). Wavellite crystals belong to the space group Pcmn. Non-oxygen elements detected by SEM-EDS were Al, P, Si (traces), and F (traces). Moreover, the EDS scan indicated the absence of any other elements with $Z>3$.

Crandallite shows acicular spherulites in vugs (Figure 5e). The size of the radial crystal sprays is $4 \mu \mathrm{m}$ diameter and the length of the needles is $2 \mu \mathrm{m}$ (Figure $5 \mathrm{f}$ ). The radial-fibrous structure with trigonal prisms terminated by $\{0001\}$ is rare. Crandallite crystals belong to the space group $R 3 m$.

Cacoxenite stands out by its needle-shaped aggregates (Figure $6 b$ ). Crystals are very thin, ranging from 50 to $250 \mathrm{~nm}$ in thickness, and lengths of up to $10 \mu \mathrm{m}$ are common in this mineral development (Figure 6c). Cacoxenite occurs as hexagonal acicular prisms along $\{0001\}$ (Figure 6e,f). All cacoxenite crystallizes in the space group $P 6_{3} / \mathrm{m}$. 

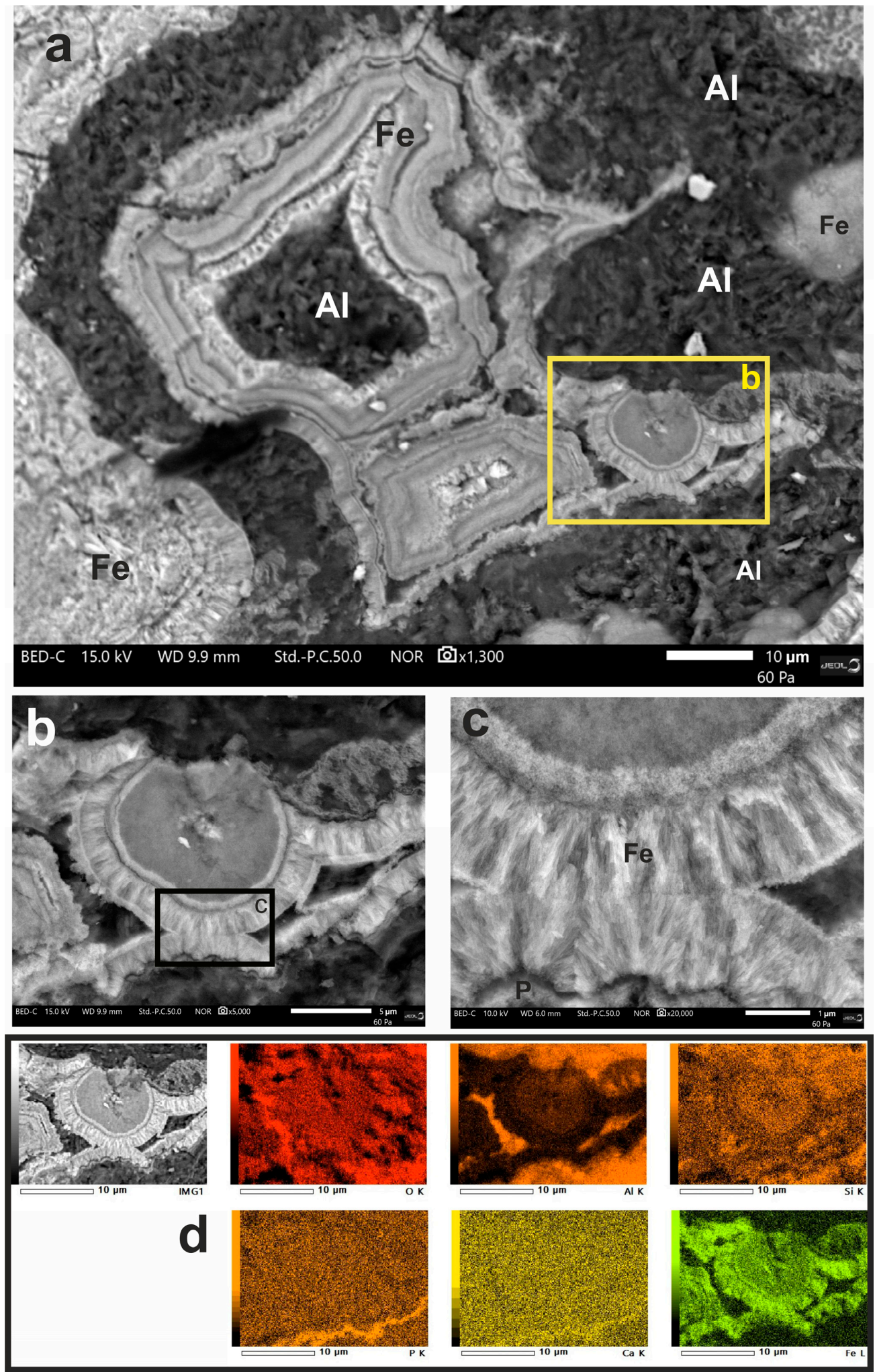

Figure 3. SEM-EDX micrographs of pisoliths with a massive structure of goethite: (a) colloform rhythmites in goethite; (b) close-up view of the mammillary-shape ferriallophane; (c) with feathery fan-shaped arrangements of goethite (goethite palisades); (d) elemental mapping of the " $b$ " surface area. Fe-iron oxides; $\mathrm{Al}$-clay minerals; $\mathrm{P}$ - phosphates. 


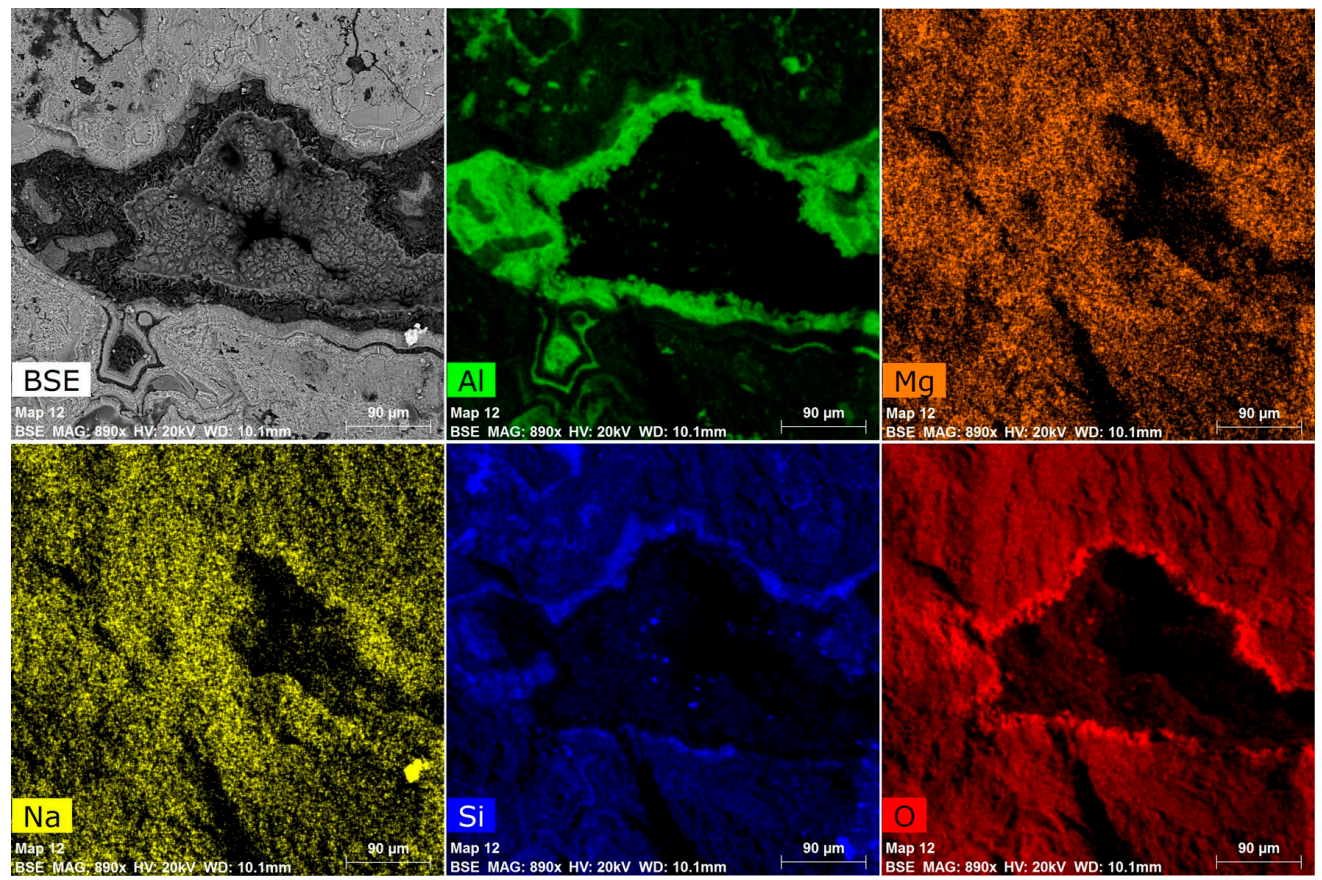

Figure 4. Elemental mapping shows that the Al-dominated minerals contain the major constituents of kaolinite.

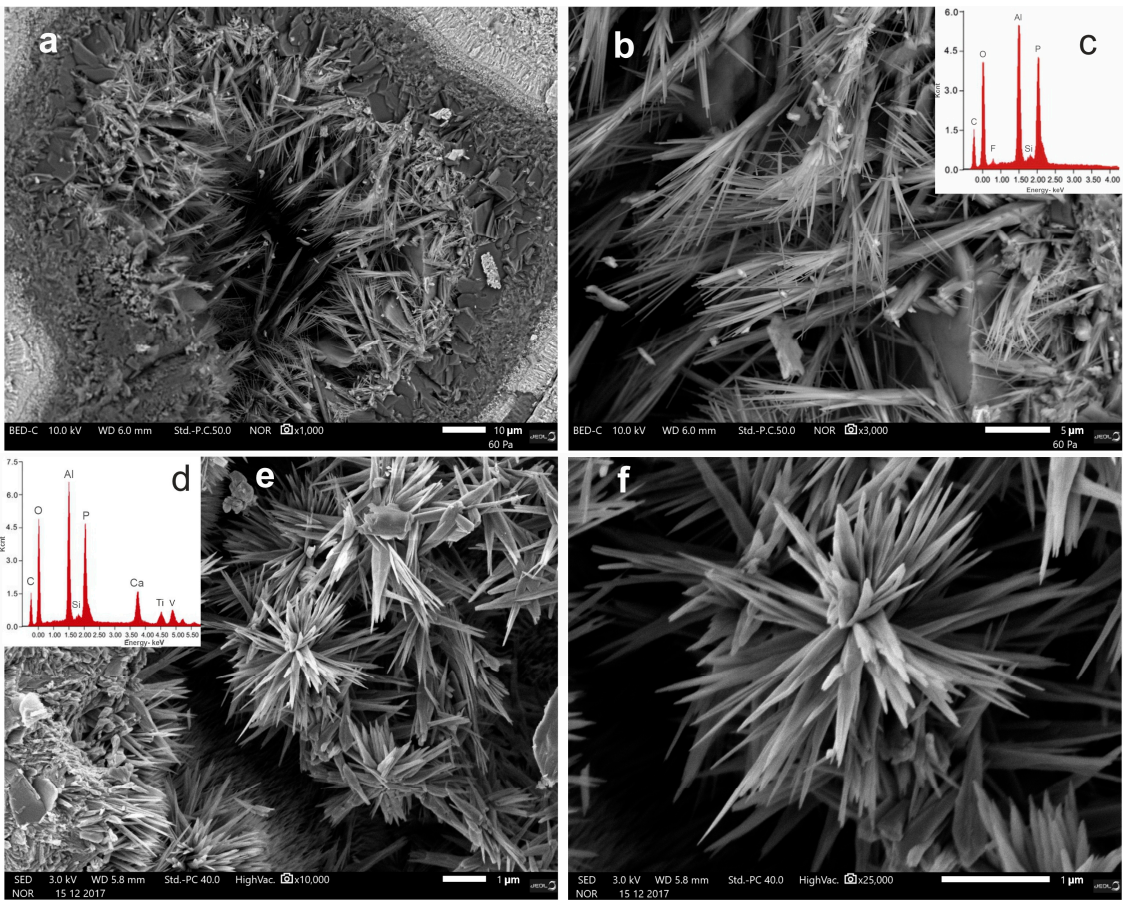

Figure 5. Wavellite and crandallite microcrystals: (a) wavellite crystals in vug; (b) needles form broom-like aggregates; (c) EDX spectrum indicates the major constituents of wavellite crystals (Al, P, F, $\mathrm{O})$; (d) EDX spectrum shows the major constituents of crandallite crystals ( $\mathrm{Al}, \mathrm{P}, \mathrm{Ca}$, O with some trace elements); (e) crandallite crystals sprays; (f) radial needles of trigonal crandallite crystals. 

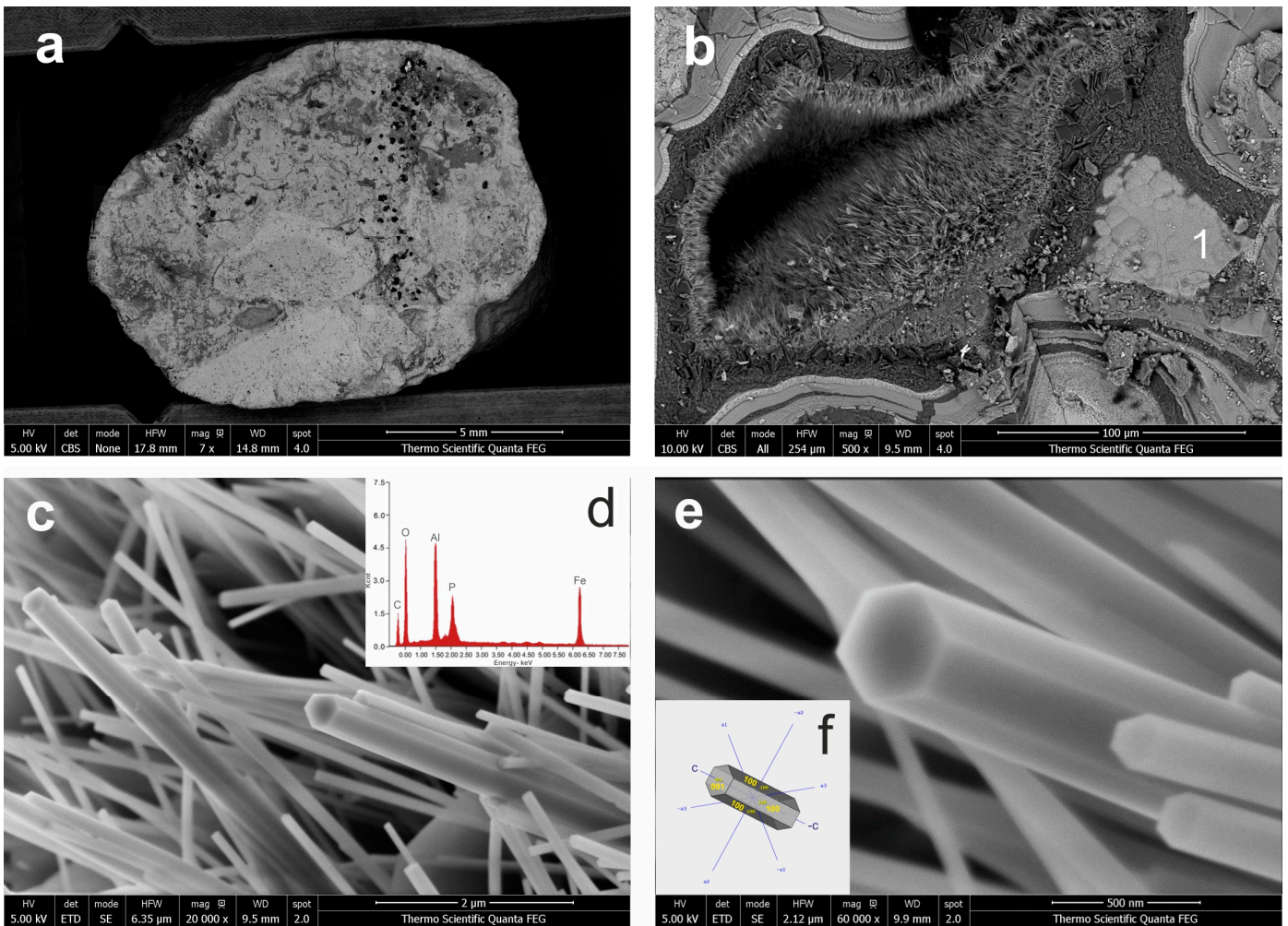

Figure 6. Cacoxenite crystals in goethite pisolith: (a) SEM micrograph of the pisolith - light gray color shows the pure goethite part; (b) needle-shaped crystals in vug; (c) bundles of cacoxenite; (d) EDX spectrum of crystals; (e) hexagonal crystals; (f) crystal habit of cacoxenite crystals with their faces denominated in the common notation of Miller's indices. 1 - botryoidal goethite surface.

\section{Discussion}

The studied samples were pisoliths and nodules with a size range of $2 \mathrm{~mm}$ to $3 \mathrm{~cm}$, dominated by goethite and hematite. These minerals are typical in terrestrial surficial conditions where the primary process is chemical precipitation of iron oxides such as hematite, and oxyhydroxides such as goethite and ferrihydrite, which displace, replace, and/or cement the original soil particles [31]. A concentric laminae fabric was not observed in any of the examined samples, (Figure 5a) which indicates the development of pisoliths above the water table in the unsaturated zone. The analyzed pisoliths and nodules have no protolith relics and contain less than 10-15\% detrital grains, showing homogeneous structures with mottled and syneresis fabrics (Figure 5a). The mottled texture resulted from unmixing and reordering of metastable oxide and hydroxide phases, while syneresis cracks and cavities were developed by dehydration of clay and Fe oxyhydroxides [31]. Fe minerals are structurally enriched during pedogenesis and often incorporated into clay minerals $[29,30,43,44]$. The detected clay mineral in the samples was mainly kaolinite. According to our previous research on these paleosols [35,36], the mean annual paleoprecipitation was $1100-1400 \mathrm{~mm}$ and the mean annual paleotemperature was $13-15^{\circ} \mathrm{C}$. In such circumstances, fersiallisation and ferruginisation are the most important processes during the diagenesis of the pisoliths and nodules. These mechanisms take place when primary minerals are moderately weathered to release iron and to form 2:1 type clay minerals (e.g., smectite group) and then the newly formed clay minerals replace metastable minerals in the protolith. These minerals are later replaced by direct precipitation of goethite, leading finally to complete ferruginisation with a 1:1 type clay mineral, such as kaolinite. Fersiallisation takes place in subtropical climates with a dry season, whereas ferruginisation arises in warmer and more humid climates. Cementation of the ferruginous particles can occur through precipitation of Fe minerals and clays during a high groundwater stand from meniscus water films [31]. 
In such a climate, soil weathering triggers dissolved phosphate from essential minerals to be adsorbed by specific substituents of iron or aluminum oxides to form thermodynamically stable complexes [16,45]. The high soil organic content (from water, rich in chelates) and low pH support goethite occurrence [23,45]. Goethite generally has a higher relative affinity for phosphorus than hematite due to its higher surface area (see Table 2) $[25,45,46]$. As opposed to kaolinite, goethite has a much higher $\mathrm{P}$ adsorption capacity, because the higher surface charge and more positive charge $\left(\mathrm{pH} \mathrm{ZPC}_{\mathrm{ZPC}}\right.$ of goethite is at ca. 8-9) of the goethite and the $\equiv \mathrm{Fe}-\mathrm{OH}$ groups are scattered throughout the entire surface of the goethite, whereas $\equiv \mathrm{Al}-\mathrm{OH}$ groups on the surface of kaolinite are situated solely at the edges of the crystal structure [47]. Hydrolysis of aluminum and iron aqua ions into oxides, hydroxides, or oxyhydroxides generates new functional groups for $\mathrm{P}$ adsorption [23]. During pedogenesis, $\mathrm{Al}$ has two ranges of solubility, below $\mathrm{pH} 6$ and above $\mathrm{pH} 8[47,48]$. In very acidic soils $(<\mathrm{pH} 3)$, monomeric $\mathrm{Al}^{3+}$ is the dominant ion in solution $[47,48]$. Along with the rising $\mathrm{pH}$, this ion becomes even more significant. All forms of soluble Al reach a minimal solubility around $\mathrm{pH} 6.5$ [47,48]. In acidic soils such as ferralsols or oxisols (as the host paleosol of the pisoliths and nodules), the aluminum has higher solubility, thus the pisoliths/nodules are depleted in Al (see in Table 3).

Phosphorus in wavellite mineralization is eventually originated from apatite mineral sources, due to the leaching action of the groundwater (during deep weathering of the red paleosol) carrying away $\mathrm{CaO}$ (from apatite) in solution. $\mathrm{Al}^{3+}$ with hydrolyzed $\mathrm{OH}-$ complexes (under acid conditions; $\mathrm{pH}$ 3-6) is probably introduced from clay minerals (illite, kaolinite) combining with the $\mathrm{P}_{2} \mathrm{O}_{5}$ from apatite, allowing wavellite development [49-51]. The phosphate speciation in solution is entirely pH-dependent $[49,52]$. Low phosphate concentration results in the formation of crandallite and wavellite $[49,53]$. Apatite was converted into crandallite in decreasing $\mathrm{pH}$ levels, with releasing part of the $\mathrm{Ca}^{2+}$ and $\mathrm{HPO}_{4}{ }^{2+}$ ions combined with dissolved $\mathrm{Al}$ [52,54]. The reaction of $\mathrm{P}_{2} \mathrm{O}_{5}$ with iron, aluminum, and calcium arises over specific $\mathrm{pH}$ conditions [49]. The maximum adsorption of phosphorus by Fe takes place at $\sim \mathrm{pH} 3.5$ and continues up to $\sim \mathrm{pH} 5.5$. Phosphorus sorption by $\mathrm{Al}$ begins around $\mathrm{pH} 4$, culminates at around $\mathrm{pH} 5.5$, and scales down to zero around $\mathrm{pH} 7$ [4,49,52]. Calcium fixation begins around $\mathrm{pH} 6$ and rises above $\mathrm{pH} 9$ [49]. Experiments on the mobility of phosphorus and aluminum in tropical and subtropical deeply weathered deposits are consistent with these constraints [49,55-58].

As stated by Wang et al. [59,60], Al varieties have a high chemical affinity for phosphorus. The AlOHP precipitates may form in solution at $\mathrm{pH} 4.5$ and be adsorbed on the goethite surfaces. The key reactant to form Al-substituted cacoxenite or wavellite is the effect of changing $\mathrm{Al}^{3+}$ ion concentrations at $\mathrm{pH} 4.5$ [60]. Cacoxenite formed by the modification of a precursor phase [1,50] and direct precipitation from interstitial waters is thermodynamically possible $[1,6,50]$. In this case, cacoxenite precipitated by the sorption of dissolved $\mathrm{P}$ from meteoric water onto goethite and the clay minerals performed as a base material for the formation of iron(III) oxide-hydroxides and provided a source of $\mathrm{Al}$ for the cacoxenite.

Adsorption of phosphate onto goethite (Figure $3 \mathrm{~d}$ ) is proven by the relative high phosphate contents of the pisoliths in contrast to the host paleosol (Table 3). This has been experimentally studied by Gao and Mucci [61], who described the simultaneous adsorption of phosphate onto iron oxyhydroxides. Following the pedological studies by Freese et al. [62] and Gustafsson [63], this type of iron mineralization is part of the formation of acidic soils such as ferralsols or oxisols, which are similar to the red paleosols of this work.

\section{Conclusions}

The studied red paleosols are weathered in a tropical/subtropical climate. In such conditions, fersiallisation and ferruginisation are the most important processes during the diagenesis of the pisoliths and nodules. The goethite pisoliths and nodules buried in paleosol have a homogeneous structure with mottled and syneresis fabrics. The newly formed precipitation products, namely wavellite, crandallite, and cacoxenite, accumulated into syneresis cracks and cavities during the weathering 
of apatite minerals. The phosphate availability is influenced by the distribution of phosphate at the goethite-water interface. Moreover, the phosphate distribution during goethite-water interaction is dependent on the solution composition, $\mathrm{pH}$, and ionic strength. During the mineral paragenesis of wavellite, crandallite, and cacoxenite, $\mathrm{pH}$ conditions in the range 4-6 are supposed to have occurred. Such $\mathrm{pH}$ values may be expected under normal tropical/subtropical weathering conditions. Well-crystalized goethite associated with Fe-Al phosphates evolved under near-ambient conditions (buried in paleosol). This mineral assemblage formed and concentrated by chemical weathering reactions at the earth's surface is a typical residual mineral deposit.

Supplementary Materials: The following are available online at http://www.mdpi.com/2075-163X/10/4/357/s1, Supplementary file: XDB dataset.

Author Contributions: J.K. conceived and designed the experiments; P.S., É.F., I.S., and J.K. performed the experiments; J.K., I.S., and É.F. analyzed the data; P.S., É.F., I.S, and J.K. wrote the paper. All authors have read and agreed to the published version of the manuscript.

Funding: This research was funded by NRDI Fund, grant number 20765-3/2018/FEKUTSTRAT and the National Research, Development and Innovation Fund: NKFI K120213. The APC was funded by the European Union, co-financed by the European Social Fund: EFOP-3.6.1.-16-2016-00004.

Acknowledgments: Special thanks go to G. Újvári (Department of Lithospheric Research, University of Vienna, Austria) for technical assistance and preparation of the samples for XRF analyses. Y. Oztan (Thermo Fisher Scientific, FEI) and J.-C. Ménard (Jeol Europe SAS.) are greatly acknowledged for helping in SEM measurements.

Conflicts of Interest: The authors declare no conflict of interest. The funders had no role in the design of the study; in the collection, analyses, or interpretation of data; in the writing of the manuscript, or in the decision to publish the results.

\section{References}

1. Nriagu, J.O. Phosphate Minerals: Their Properties and General Modes of Occurrence. In Phosphate Minerals; Nriagu, J.O., Moore, P.B., Eds.; Springer: Berlin/Heidelberg, Germany, 1984; pp. 1-136.

2. Moore, P.B.; Shen, J. An X-ray structural study of cacoxenite, a mineral phosphate. Nature 1983, 306, 356-358. [CrossRef]

3. Anthony, J.W.; Bideaux, R.A.; Bladh, K.W.; Nichols, M.C. Handbook of Mineralogy, Volume IV. Arsenates, Phosphates, Vanadates, 1st ed.; Mineral Data Publishing: Tucson, AZ, USA, 2000; p. 88.

4. Dill, H.G.; Weber, B.; Kaufhold, S. The origin of siderite-goethite-phosphate mineralization in the karst-related faultbound iron ore deposit Auerbach, Germany, a clue to the timing of hypogene and supergene Fe-Al phosphates in NE Bavaria. Neues Jahrb. Mineral. Abh. 2009, 186, 283-307. [CrossRef]

5. Mills, S.J. A note on perhamite from the Moculta (Klemms) phosphate quarry, South Australia. Aust. J. Miner. 2003, 9, 43-45.

6. Hearn, P.P.J.; Mccartan, L.; Soller, D.R.; Krohn, M.D.; Gonzalez, V.M. Cacoxenite in Miocene Sediments of the Maryland Coastal Plain. Clays Clay Miner. 1988, 36, 419-424. [CrossRef]

7. Steinmann, J. Kákoxèn. Archiv. Für. Die Gesammte Nat. 1826, 8, 446.

8. Nunes, A.P.L.; Peres, A.E.C.; Araujo, A.C.; Valadao, G.E.S. Electrokinetic properties of wavellite and its floatability with cationic and anionic collectors. J. Colloid Interface Sci. 2011, 361, 632-638. [CrossRef]

9. Huminicki, D.M.C.; Hawthorne, F.C. The Crystal Chemistry of the Phosphate Minerals. Rev. Mineral. Geochem. 2002, 48, 123-253. [CrossRef]

10. Bayliss, P.; Kolitsch, U.; Nickel, E.H.; Pring, A. Alunite supergroup: Recommended nomenclature. Mineral. Mag. 2010, 74, 919-927. [CrossRef]

11. Blount, A.M. The crystal structure of crandallite. Am. Miner. 1974, 59, 41-47.

12. Tiessen, H.; Stewart, J.W.B.; Cole, C.V. Pathways of Phosphorus Transformations in Soils of Differing Pedogenesis. Soil Sci. Soc. Am. J. 1984, 48, 853-858. [CrossRef]

13. Schwertmann, U.; Schieck, E. Das Verhalten von Phosphat in eisenoxidreichen Kalkgleyen der Münchnener Schotterebene. Z. Pflanz. Bodenkund. 1980, 143, 391-401. [CrossRef]

14. Tiessen, H.; Lo Monaco, S.; Ramirez, A.; Santos, M.C.D.; Shang, C. Phosphate minerals in a lateritic crust from Venezuela. Biogeochemistry 1996, 34, 1-17. [CrossRef] 
15. Antelo, J.; Arce, F.; Avena, M.; Fiol, S.; López, R.; Macías, F. Adsorption of a soil humic acid at the surface of goethite and its competitive interaction with phosphate. Geoderma 2007, 138, 12-19. [CrossRef]

16. Fink, J.R.; Inda, A.V.; Bavaresco, J.; Barrón, V.; Torrent, J.; Bayer, C. Adsorption and desorption of phosphorus in subtropical soils as affected by management system and mineralogy. Soil Tillage Res. 2016, 155, 62-68. [CrossRef]

17. Bardossy, G.; Aleva, G.J.J. Lateritic Bauxites-Developments in Economic Geology 27; Elsevier: Amsterdam, The Netherlands, 1990; pp. 1-624.

18. Boulange, B.; Ambrosi, J.P.; Nahon, D. Laterites and Bauxites. In Soils and Sediments; Paquet, H., Clauer, N., Eds.; Springer: Berlin/Heidelberg, Germany, 1997; pp. 49-65.

19. Dill, H.G.; Melcher, F.; Gerdes, A.; Weber, B. The origin and zoning of hypogene and supergene Fe-Mn-Mg-Sc-UREE-Zn phosphate mineralization from the newly discovered Trutzhofmühle aplite (Hagendorf pegmatite province, Germany). Can. Mineral. 2008, 46, 1131-1157. [CrossRef]

20. Kämpf, N.; Schwertmann, U. The $5 \mathrm{M}-\mathrm{NaOH}$ concentration treatment for iron oxides in soils. Clays Clay Miner. 1982, 30, 401-408. [CrossRef]

21. Schaefer, C.; Fabris, J.; Ker, J. Minerals in the clay fraction of Brazilian Latosols (Oxisols): A review. Clay Miner. 2008, 43, 137-154. [CrossRef]

22. Carvalho Filho, A.; Inda, A.V.; Fink, J.R.; Curi, N. Iron oxides in soils of different lithological origins in Ferriferous Quadrilateral (Minas Gerais, Brazil). Appl. Clay Sci. 2015, 118, 1-7. [CrossRef]

23. Fink, J.R.; Inda, A.V.; Tiecher, T.; Barrón, V. Iron oxides and organic matter on soil phosphorus availability. Ciênc. Agrotec. 2016, 40, 369-379. [CrossRef]

24. Cornell, R.M.; Schwertmann, U. The Iron Oxides; VCH Verlag: Weinheim, Germany, 2003; pp. 1-664.

25. Guzman, G.; Alcantara, E.; Barrón, V.; Torrent, J. Phytoavailability of phosphate adsorbed on ferrihydrite, hematite, and goethite. Plant Soil 1994, 159, 219-225. [CrossRef]

26. Adeleye, D.R. Origin of ironstones, an example from the middle Niger Valley, Nigeria. J. Sed. Petrol. 1973, 43, 709-723.

27. Glassford, D.K.; Semeniuk, V. Desert-aeolian origin of late Cenozoic regolith in arid and semi-arid Southwestern Australia. Palaeogeogr. Palaeoclim. Palaeoecol. 1995, 114, 131-166. [CrossRef]

28. Anand, R.R.; Paine, M. Regolith geology of the Yilgarn Craton, Western Australia: Implications for exploration. Aust. J. Earth Sci. 2002, 49, 3-162. [CrossRef]

29. Lascelles, D.F. The origin of terrestrial pisoliths and pisolitic iron ore deposits: Raindrops and sheetwash in a semi-arid environment. Sed. Geol. 2016, 341, 232-244. [CrossRef]

30. Maciag, Ł.; Rydzewska, U.; Skowronek, A.; Salwa, S. Mineralogy and Geochemistry of Fluvial-Lacustrine Pisolith Micronodules from the Roztoka Odrzańska, Odra River, NW Poland. Geosciences 2019, 10, 3. [CrossRef]

31. Clarke, J.D.A.; Chenoweth, L. Classification, genesis and evolution of ferruginous surface grains. AGSO J. Aust. Geol. Geophys. 1996, 16, 213-221.

32. Bourman, R.P. Modes of ferricrete genesis-evidence from southeastern Australia. Z. Geomorph. 1993, 37, 77-101.

33. Schulz, M.S.; Vivit, D.; Schulz, C.; Fitzpatrick, J.; White, A. Biologic Origin of Iron Nodules in a Marine Terrace Chronosequence, Santa Cruz, California. Soil Sci. Soc. Am. J. 2010, 74, 550-564. [CrossRef]

34. Löhr, S.C.; Grigorescu, M.; Cox, M.E. Iron nodules in ferric soils of the Fraser Coast, Australia: Relicts of laterisation or features of contemporary weathering and pedogenesis? Soil Res. 2013, 51, 77-93. [CrossRef]

35. Kovács, J.; Fábián, S.A.; Varga, G.; Újvári, G.; Varga, G.; Dezső, J. Plio-Pleistocene red clay deposits in the Pannonian basin: A review. Quat. Int. 2011, 240,35-43. [CrossRef]

36. Kovács, J.; Raucsik, B.; Varga, A.; Újvári, G.; Varga, G.; Ottner, F. Clay mineralogy of red clay deposits from the central Carpathian Basin (Hungary): Implications for Plio-Pleistocene chemical weathering and palaeoclimate. Turk. J. Earth Sci. 2013, 22, 414-426.

37. Feret, F.R. Mining: Mineral ores and products. In Industrial Applications of X-ray Diffraction; Chung, F.H., Smith, D.K., Eds.; Marcel Dekker, Inc.: New York, NY, USA; Basel, Switzerland, 2000; pp. 385-414.

38. Ritchie, N.; Newbury, D.; Davis, J. EDS Measurements of X-Ray Intensity at WDS Precision and Accuracy Using a Silicon Drift Detector. Microsc. Microanal. 2012, 18, 892-904. [CrossRef] [PubMed] 
39. Salge, T.; Neumann, R.; Andersson, C.; Patzschke, M. Advanced mineral classification using feature analysis and spectrum imaging with EDS. In 23rd International Mining Congress and Exhibition of Turkey (IMCET 2013); Bengu, I., Gulsun, M., Eds.; Chamber of Mining Engineers of Turkey: Ankara, Turkey, 2013; pp. 357-367.

40. Schulz, B.; Merker, G.; Gutzmer, J. Automated SEM Mineral Liberation Analysis (MLA) with Generically Labelled EDX Spectra in the Mineral Processing of Rare Earth Element Ores. Minerals 2019, 9, 527. [CrossRef]

41. Rumble, J. CRC Handbook of Chemistry and Physics; Taylor \& Francis Ltd.: Boca Raton, FA, USA, 2019; pp. 1-1532.

42. Kovács, J.; Varga, G.; Dezső, J. Comparative study on the Late Cenozoic red clay sediments from China and Central Europe (Hungary). Geol. Quart. 2008, 52, 369-382.

43. Tardy, Y. Petrology of Laterites and Tropical Soils; A.A. Balkema Publishers: Rotterdam, The Netherlands, 1997; pp. 1-419.

44. Gebru, Y.; Elueze, A.A.; Amare, K.; Dongmo, F.W.N. Compositional characteristics and genetic affinity of the ferricrete deposit in Adi Kokeb district, northwestern Tigray, Ethiopia. Appl. Earth Sci. 2019, 128, 146-157. [CrossRef]

45. Bortoluzzi, E.C.; Pérez, C.A.S.; Ardisson, J.D.; Tiecher, T.; Caner, L. Occurrence of iron and aluminum sesquioxides and their implications for the P sorption in subtropical soils. Appl. Clay Sci. 2015, 104, 196-204. [CrossRef]

46. Wang, X.; Liu, F.; Tan, W.; Li, W.; Feng, X.; Sparks, D.L. Characteristics of Phosphate Adsorption-Desorption Onto Ferrihydrite: Comparison With Well-Crystalline Fe (Hydr)Oxides. Soil Sci. 2013, 178, 1-11. [CrossRef]

47. Wei, S.; Tan, W.; Liu, F.; Zhao, W.; Weng, L. Surface properties and phosphate adsorption of binary systems containing goethite and kaolinite. Geoderma 2014, 213, 478-484. [CrossRef]

48. Driscoll, C.T.; Schecher, W.D. The chemistry of aluminum in the environment. Environ. Geochem. Health 1990, 12, 28-49. [CrossRef]

49. Kampf, A.R.; Adams, P.M.; Barwood, H.; Nash, B.P. Fluorwavellite, $\mathrm{Al}_{3}\left(\mathrm{PO}_{4}\right)_{2}(\mathrm{OH})_{2} \mathrm{~F} \cdot 5 \mathrm{H}_{2} \mathrm{O}$, the fluorine analog of wavellite. Am. Mineral. 2017, 102, 909-915. [CrossRef]

50. Flicoteaux, R.; Lucas, J. Weathering of phosphate minerals. In Phosphate Minerals; Nriagu, J.O., Moore, P.B., Eds.; Springer: Berlin/Heidelberg, Germany, 1984; pp. 292-317.

51. Gnandi, K.; Tobschall, H.J. Distribution patterns of rare-earth elements and uranium in tertiary sedimentary phosphorites of Hahotoé-Kpogamé, Togo. J. Afr. Earth Sci. 2003, 37, 1-10. [CrossRef]

52. Dill, H.G. The geology of aluminium phosphates and sulphates of the alunite group minerals: A review. Earth-Sci. Rev. 2001, 53, 35-93. [CrossRef]

53. Nriagu, J.O. Phosphate-clay mineral relations in soils and sediments. Can. J. Earth Sci. 1976, 13, 717-736. [CrossRef]

54. Salama, W. Paleoenvironmental significance of aluminum phosphate-sulfate minerals in the upper Cretaceous ooidal ironstones, E-NE Aswan area, southern Egypt. Int. J. Earth Sci. 2014, 103, 1621-1639.

55. Goldberg, S.; Sposito, G. A chemical model of phosphate adsorption by soils. II. Noncalcareous soils. Soil Sci. Soc. Am. J. 1984, 48, 779-783.

56. Huang, W.H.; Keller, W.D. Geochemical mechanics for the dissolution, transport, and deposition of aluminum in the zone of weathering. Clays Clay Miner. 1972, 20, 69-74.

57. Vieillard, P.; Tardy, Y.; Nahon, D. Stability fields of clays and aluminum phosphates; parageneses in lateritic weathering of argillaceous phosphatic sediments. Am. Mineral. 1979, 64, 626-634.

58. Nickel, E. Experimental dissolution of light and heavy minerals in comparison with weathering and intrastratal solution. Contrib. Sediment. 1973, 1, 1-68.

59. Wang, L.; Putnis, C.V.; Ruiz-Agudo, E.; Hövelmann, J.; Putnis, A. In situ Imaging of Interfacial Precipitation of Phosphate on Goethite. Environ. Sci. Technol. 2015, 49, 4184-4192. [CrossRef]

60. Wang, L.; Putnis, C.V.; Hövelmann, J.; Putnis, A. Interfacial Precipitation of Phosphate on Hematite and Goethite. Minerals 2018, 8, 207. [CrossRef]

61. Gao, Y.; Mucci, A. Acid base reactions, phosphate and arsenate complexation, and their competitive adsorption at the surface of goethite in $0.7 \mathrm{M} \mathrm{NaCl}$ solution. Geochim. Cosmochim. Acta. 2001, 65, 2361-2378. [CrossRef] 
62. Freese, D.; Lookman, R.; Merckx, R.; van Riemsdijk, W.H. New Method for Assessment of Long-Term Phosphate Desorption from Soils. Soil Sci. Soc. Am. J. 1995, 59, 1295-1300. [CrossRef]

63. Gustafsson, J.P. Modelling competitive anion adsorption on oxide minerals and an allophane-containing soil. Eur. J. Soil Sci. 2001, 52, 639-653. [CrossRef] 